\title{
Electrochemical Feasibility Study of Methyl Parathion Determination on Graphite- Modified Basal Plane Pyrolytic Graphite Electrode
}

\author{
Leonardo Luiz Okumura, ${ }^{*}, a$ Adelir Aparecida Saczk, ${ }^{b}$ Marcelo Firmino de Oliveira, ${ }^{c}$ \\ Ana Carolina C. Fulgêncio, ${ }^{a}$ Larissa Torrezani, ${ }^{a}$ Paulo Eduardo N. Gomes ${ }^{a}$ and \\ Rosana M. Peixoto ${ }^{a}$
}

\author{
a Departamento de Química, Universidade Federal de Viçosa, 36570-000 Viçosa-MG, Brazil \\ ${ }^{b}$ Departamento de Química, Universidade Federal de Lavras, 37200-000 Lavras-MG, Brazil \\ ${ }^{c}$ Departamento de Química, Universidade de São Paulo, FFCLRP, 14040-901 Ribeirão Preto-SP, Brazil
}

Um método eletroquímico de baixo custo foi desenvolvido para a determinação de traços de metil paration (MP) baseado nas propriedades do eletrodo de grafite pirolítico de plano basal modificado com grafite (grafite-bppg). A combinação do grafite-bppg com voltametria de onda quadrada (VOQ) resultou em um método eletroquímico seletivo, sensível e original para a determinação do pesticida MP em água potável. O eletrodo foi construído e o comportamento eletroquímico do MP foi estudado. A imobilização foi feita através de modificação por formação de filme a partir da dispersão de pó de grafite em água destilada e através de pipetagem de um volume pequeno sobre a superfície do eletrodo, permitindo que o solvente volatilizasse. A forte afinidade do modificador grafite com o grupo fósforo do MP permitiu o depósito de uma quantidade significativa de MP em menos de 60 segundos. Os resultados de voltametria cíclica mostraram que o eletrodo de grafite-bppg pode aumentar a sensibilidade na intensidade de corrente para os picos redox quasi-reversíveis dos produtos da redução catódica do grupo nitro em potencial negativo (pico I $=0,077 \mathrm{~V}$ e o pico II $=-0,062 \mathrm{~V}$ ) e para o pico catódico irreversível (pico III $=-0,586 \mathrm{~V}$ ) em comparação com o eletrodo não modificado bppg e que o processo é também controlado por adsorção. Sob condições otimizadas, o intervalo de concentração e limite de detecção para o pesticida MP são 79,0 a 263,3 $\mu \mathrm{mol} \mathrm{L} \mathrm{L}^{-1}$ e 3,00 $\mu \mathrm{mol} \mathrm{L} \mathrm{L}^{-1}$, respectivamente. O método proposto foi aplicado com sucesso à determinação do MP em água potável e o desempenho deste sensor eletroquímico foi avaliado em termos de figuras de mérito analíticas.

A low-cost electrochemical method was developed for the determination of trace-level of methyl parathion (MP) based on the properties of graphite-modified basal plane pyrolytic graphite electrode (graphite-bppg). A combination of graphite-bppg with square-wave voltammetric (SWV) analysis resulted in an original, sensitive and selective electrochemical method for determination of MP pesticide in drinking water. The electrode was constructed and the electrochemical behavior of MP was studied. Immobilization is achieved via film modification from dispersing graphite powder in deionized water and through pipeting a small volume onto the electrode surface allowing the solvent to volatilize. The strong affinity of the graphite modifier for the phosphorous group of the MP allowed the deposition of a significant amount of MP in less than 60 seconds. The cyclic voltammetric results indicate that the graphite-bppg electrode can enhance sensitivity in current intensity towards the quasi-reversible redox peaks of the products of the cathodic reduction of the nitro group at negative potential (peak $\mathrm{I}=0.077 \mathrm{~V}$ and peak $\mathrm{II}=-0.062 \mathrm{~V}$ ) and that the cathodic irreversible peak (peak III $=-0.586 \mathrm{~V}$ ) in comparison with bare bppg electrode and is also adsorption controlled process. Under optimized conditions, the concentration range and detection limit for MP pesticide are respectively 79.0 to $263.3 \mu \mathrm{mol} \mathrm{L} \mathrm{L}^{-1}$ and $3.00 \mu \mathrm{mol} \mathrm{L}^{-1}$. The proposed method was successfully applied to MP determination in drinking water and the performance of this electrochemical sensor has been evaluated in terms of analytical figures of merit.

Keywords: methyl parathion, basal plane pyrolytic graphite electrode, square-wave voltammetry, graphite, drinking water

*e-mail: leo.okumura@ufv.br 


\section{Introduction}

Organophosphorous (OP) compounds are the most important agrochemical used in the Brazilian agriculture and are significant environmental and food chain pollutants ${ }^{1}$ because they are used intensively as pesticides, insecticides and chemical-warfare agents. Their uninformed use can cause food, water, soil, etc contamination and, due to its high toxicity, rapid detection of these toxic compounds has become increasingly important for homeland security and health protection. ${ }^{2,3}$ Methyl parathion (MP), $O, O$-dimethyl$O$-(4-nitrophenyl) thiophosphate (Figure 1), is an organophosphorous insecticide which is very effective against many pathogenic agents and pests in important crops such as cereals, vegetables, soybean, sugar cane, coffee, that possess economic relevance. MP contamination is normally through manual contact, ingestion or inhalation. MP is also a well-known inhibitor of acetylcolinesterase that is essential for the normal operation of the central nervous system of insects, resulting in serious damage and death. ${ }^{4}$ For classification purposes MP is included in toxicological class 1 , meaning that it is extremely dangerous for mammals.

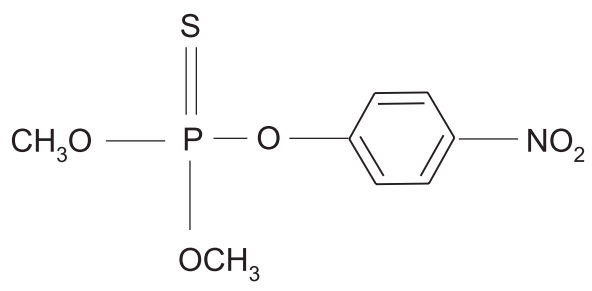

Figure 1. Chemical structure of methyl parathion.

Analysis of OPs in the environment is routinely carried out using gas or liquid chromatography associated with mass spectrometry or others detectors..$^{5-13}$ Although chromatography techniques have been widely applied, they are time-consuming, solvent-usage intensive, require expensive equipment and maintenance, and often result in a lengthy turnaround of pretreatment steps. For all these reasons, the faster and more economic electrochemical detection of pesticides including OPs is a very desirable. Moreover, it is a widely used method in analytical chemistry and has the additional benefit of being compatible with the principles of green chemistry.

Among OP compounds, MP exhibits good redox activities at some electrode surfaces. ${ }^{3}$ In the last decade, more attention has been given to their inherent electrochemical activity on mercury electrodes. ${ }^{14-16}$ However, the use of mercury-based electrodes is now considered incompatible with environmental objectives. Moreover, the modification of electrode substrates with carbon nanotubes (CNTs) and several types of nanoparticles has been recently documented to result in low detection limits, high sensitivities, reduction of over potentials, resistance to surface fouling, and electrocatalytic properties. ${ }^{17}$ Compton et al. ${ }^{18,19}$ have extensively explored the origins of these reported electrocatalytic responses of carbon nanotubes which they attribute to edge plane-like sites/defects occurring at the ends of the open tubes and along the tube axis. Others papers in the same research group explored the role of metallic impurities in MWCNTs (multi-walled cabon-nanotubes) on their electrochemical response demonstrating that iron oxide impurities, which are used in chemical vapor deposition (CVD) fabrication process to fabricate the MWCNTs, can dominate the electrochemical response of the MWCNTs. ${ }^{20,21}$

Recently and more significant, MWCNT-modified glassy carbon electrode (MWCNT-GCE), zirconia nanoparticles-chitosan-modified glassy carbon electrode ( $\mathrm{ZrO}_{2}$-CHIT-GCE), carbon paste electrode modified with mesoporous zirconia $\left(\mathrm{ZrO}_{2}-\mathrm{CPE}\right)$, electrochemical deposition of silicate-cetyltrimethylammonium bromide nanocomposite film on glassy carbon electrode (Si-CTA-GCE), poly-L-cysteine film-modified glassy carbon electrode (LCys-GCE) and bismuth-film modified glassy carbon electrode (BiF-GCE) have also been reported to be suitable for the detection of MP pesticide. $22-28$

Despite of all of the advantages presented above on the use of glassy carbon electrode (or others electrode surfaces) modified by CNTs and/or several (nano)particles, the graphite-bppg electrode has not been evaluated in terms of electroanalytical use and electrocatalystic effects, and to assess whether it is characterized by the same features mentioned. Furthermore, we evaluated if the graphite used in the modification of the electrode has the same advantages to the nanomaterials and nanoparticles used in papers cited previously, and if the electron transfer process is facilitated. The assessment of this study will propose the replacement of such nanoparticles and nanomaterials in the construction of new electrodes taking into account the cost of production using only the graphite in the modification process.

Additionally, to the best of our knowledge, anodic stripping voltammetric determination of MP using a graphite-bppg electrode has not been reported in the literature. The aim of the present work is to develop a convenient and sensitive method for the determination of MP based on the unusual, and not fully explored, properties of graphite as a modifier. ${ }^{29}$ Finally, this modified electrode is used for analysis of MP in drinking water samples collected close to a coffee crop in Viçosa, Minas Gerais, Brazil. 


\section{Experimental}

\section{Reagents}

All chemicals were of analytical grade and were used without any further purification. MP was supplied by SigmaAldrich (> 99\%, St. Louis, USA) and a stock solution of $38 \mathrm{mmol} \mathrm{L}^{-1}$ was prepared in methanol (Fisher, HPLC grade, USA) and used in all experiments. Graphite powder was obtained commercially from Merck (product number 1042062500 , black powder, $\geq 99.5 \%$, particle size $<50 \mu \mathrm{m}$, Germany). Acetate buffer solution was purchased by Acros Organics ( $>99 \%$, Belgium) and $\mathrm{pH}$ was adjusted with $\mathrm{NaOH}$ $0.1 \mathrm{~mol} \mathrm{~L}^{-1}$ solution (Vetec, Brazil). All solutions were prepared with deionized water of resistivity not higher than 18.2 $\mathrm{M} \Omega \mathrm{cm}^{-1}$ (Millipore, Milli-Q System, USA).

\section{Instrumentation}

Voltammetric measurements were carried out using a $\mu$-Autolab type III (Eco-Chemie, The Netherlands) potentiostat. All measurements were conducted using a three-electrode configuration. A homemade basal plane pyrolytic graphite electrode in polytetrafluorethilene polymer (5 mm diameter, Le Carbone Ltd, Sussex, U.K.) was used as the working electrode. The counter electrode was a bright platinum bare (diameter $5 \mathrm{~mm}$ and length $50 \mathrm{~mm}$, Eco-Chemie, Netherlands). Finally, the reference electrode used was $\mathrm{Ag} \mid \mathrm{AgCl}, \mathrm{KCl} 3.0 \mathrm{~mol} \mathrm{~L}^{-1}$ (Eco-Chemie, Netherlands). The $\mathrm{pH}$ of the solutions was measured using a pHmeter from Metrohm, model 826.

\section{Preparation and modification of the electrode}

The graphite-bppg electrode was prepared using exactly the same procedure described by Compton et al. ${ }^{29}$ with the slight difference that the film of graphite powder was formed via dispersion of $18.0 \mathrm{~g}$ of graphite power in $15.0 \mathrm{~mL}$ of deionized water under sonicated conditions for $15 \mathrm{~min}$. Other types of dispersion were evaluated using the acetonitrile, methanol and DMF, however the results were unsatisfactory due to the lack of reproducibility of the electrochemistry measurements. Additionally, no effects of blocking or fouling surface was obtained using the graphitebppg electrode, even when leach out of the graphite film in aqueous solutions during the electrochemical experiments. Before each experiment the bppg electrode was first polished on a polishing cloth with an aqueous suspension of 0.05 and $0.30 \mu \mathrm{m}$ alumina slurry solution and ultrasonically cleaned for $5 \mathrm{~min}$ in a 1/1 ethanol: $\mathrm{H}_{2} \mathrm{O}$ mixture, then rinsed with distilled water and dried at room temperature.
The electroactive areas of both bare bppg and graphitebppg electrodes were obtained by cyclic voltammetry $(\mathrm{CV})$ using $\mathrm{K}_{3}\left[\mathrm{Fe}(\mathrm{CN})_{6}\right]$ as a probe at different scan rates in $25^{\circ} \mathrm{C}$. For a reversible process at $25^{\circ} \mathrm{C}$, the RandlesSevcik formula has been used: ${ }^{30}$

$\mathrm{i}_{\mathrm{pa}}=\left(2.69 \times 10^{5}\right) \mathrm{n}^{3 / 2} \mathrm{~A} \mathrm{D}_{\mathrm{R}}^{1 / 2} \mathrm{C}_{\mathrm{o}} v^{1 / 2}$

where $i_{p a}$ refers to the anodic peak current, $n$ is the number of electrons transferred, $\mathrm{A}$ is the surface area of the electrode, $D_{R}$ is diffusion coefficient, $v$ is the scan rate and $\mathrm{C}_{\mathrm{o}}$ is the concentration of $\mathrm{K}_{3}\left[\mathrm{Fe}(\mathrm{CN})_{6}\right]$. For $5.0 \mathrm{mmol} \mathrm{L}^{-1}$ $\mathrm{K}_{3}\left[\mathrm{Fe}(\mathrm{CN})_{6}\right]$ in $0.50 \mathrm{~mol} \mathrm{~L}^{-1} \mathrm{KCl}$ electrolyte, $\mathrm{n}=1$, $D_{R}=7.6 \times 10^{-6} \mathrm{~cm}^{2} \mathrm{~s}^{-1}$, then from the slope of the plot of $\mathrm{i}_{\mathrm{pa}}$ versus $\mathrm{v}^{1 / 2}$ relation, the electroactive areas were calculated. In bare bppg, the electrode surface was found to be $0.196 \mathrm{~cm}^{2}$ and for graphite-modified bppg, and the surface was nearly 4-4.5 times greater.

\section{Electrochemical stripping detection of MP}

The determination of MP included one main step, as is usual for an analytical procedure. The graphite-bppg electrode was immersed into a stirred $10.0 \mathrm{~mL}$ sample solution containing desired concentration of MP by an accumulation potential during a given time, and then anodic stripping SWV measurements were undertaken. Several electrochemical methods of analysis were applied, such as linear sweep (LSV), differential-pulse (DPV) and square wave voltammetry (SWV). All measurements were carried out at $25.0 \pm 0.1^{\circ} \mathrm{C}$ and were also obtained in triplicate. An analytical curve of MP in $0.20 \mathrm{~mol} \mathrm{~L}^{-1}$ acetate buffer ( $\mathrm{pH}$ 5.2) was obtained by standard addition of MP with concentrations ranging from 79.0 to $263.3 \mu \mathrm{mol} \mathrm{L}-1$ using the anodic stripping SWV technique. To study the accuracy of the proposed method and to check the interferences, recovery experiments were carried out in the drinking water samples $(9.00 \mathrm{~mL}$ of the sample $+1.00 \mathrm{~mL}$ of the $2.0 \mathrm{~mol} \mathrm{~L}^{-1}$ acetate buffer solution and $\mathrm{pH}$ adjusted to 5.2).

\section{Results and Discussion}

\section{Cyclic voltammetry behavior of $M P$}

All voltammetric measurements were carried out using an already optimized $0.20 \mathrm{~mol} \mathrm{~L}^{-1}$ acetate buffer ( $\mathrm{pH} 5.2$ ) system, which promotes complete solubilization of the MP and is also characterized by an improvement of the potential window. ${ }^{22-24}$ The cyclic voltammograms of MP at a bare bppg and at graphite-modified bppg electrode are shown in Figure 2. The products of the cathodic reduction 
of the nitro group at negative potential of MP at the bare bppg exhibited weak and broad peaks due to the possible slow electron transfer, while the response was considerably improved at the graphite-modified bppg electrode. At the bare bppg, the peaks were at about $0.085 \mathrm{~V}$ (peak I) and $-0.007 \mathrm{~V}$ (peak II) for a quasi-reversible redox couple and $-0.600 \mathrm{~V}$ for a cathodic irreversible peak, but on the graphite-modified bppg the peaks appeared at $0.077 \mathrm{~V}$ (peak I) and $-0.062 \mathrm{~V}$ (peak II) and $-0.586 \mathrm{~V}$ (peak III) with considerable enhancement in the peak current (factor of 7.3 increase in the reversible peak current) and a slight shift to less positive and negative values of potential. This was also attributed to the effect caused by graphite as a modifier.

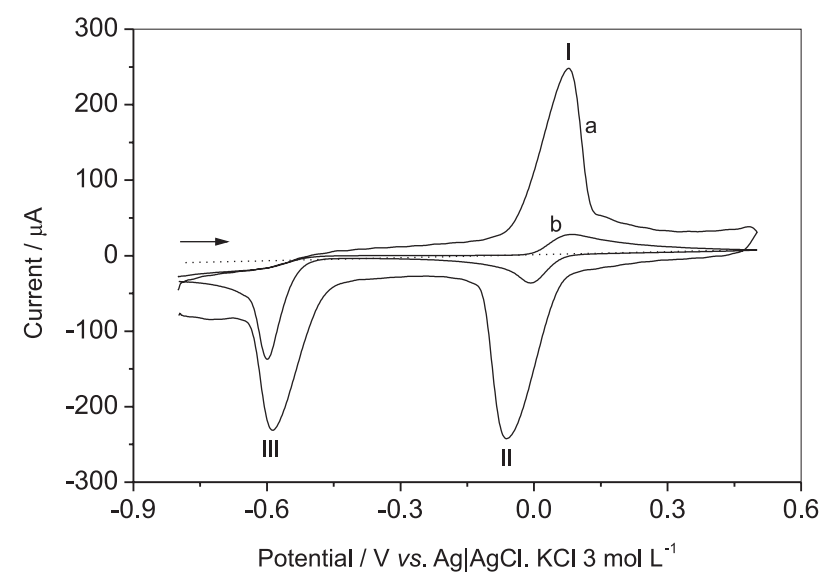

Figure 2. Cyclic voltammetric measurements of $5.0 \mathrm{mmol} \mathrm{L}^{-1} \mathrm{MP}$ on graphite-modified bppg (a) and bare bppg (b). Blank CV is showed as dot line. CV parameters: scan rate $100 \mathrm{mV} \mathrm{s}^{-1}$; supporting electrolyte $0.20 \mathrm{~mol} \mathrm{~L}^{-1}$ acetate buffer $\mathrm{pH} 5.2$ and volume of graphite suspension as a modifier of $10.0 \mu \mathrm{L}$.

A well-known mechanism to understand MP redox reactions has been already proposed ${ }^{23}$ and suggests that an irreversible reduction peak is attributable to the reduction of the nitro group to the correspondent hydroxylamine group and the quasi-reversible redox peaks to a fast two-electrontransfer process at the glassy carbon electrode.

Additionally, in order to understand the electrochemical behavior of MP still using $\mathrm{CV}$, after the second sweep, the peak current decreased greatly and finally remained unchanged $\left(1^{\text {st }}\right.$ outer and $10^{\text {th }}$ inner cycle, Figure 3$)$. This phenomenon may be due to the fact that the adsorption of MP or its redox products that occurs at the film electrode surface produces fouling behavior of the graphite-modified bppg electrode. Therefore, for analytical purposes, the voltammograms corresponding to the first cycle and peak I was generally recorded.

Useful information about electrochemical mechanisms can usually be acquired from the relationship between peak current and scan rate by $\mathrm{CV}$ measurements. Therefore, the

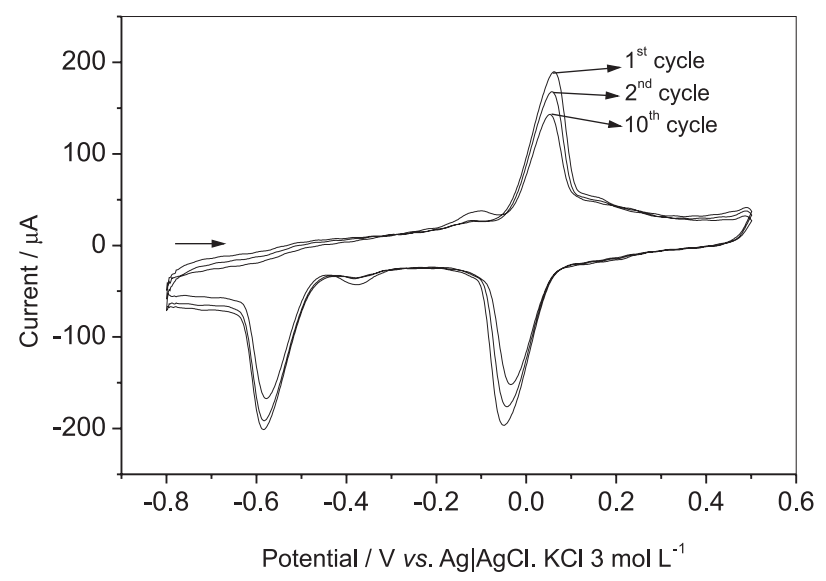

Figure 3. Sucessive cyclic voltammograms of $3.0 \mathrm{mmol} \mathrm{L}^{-1} \mathrm{MP}$ on graphite-modified bppg electrode. Other conditions and parameters are showed as in Figure 2.

electrochemical behavior of MP at different scan rates from 0.010 to $0.300 \mathrm{~V} \mathrm{~s}^{-1}$ was also studied in the graphite-modified bppg electrode. There is a good linear relationship between peak current and scan rate as indicated by Figure 4 in the scan rate range of 10 and $300 \mathrm{mV} \mathrm{s}^{-1}$. The equations are $\mathrm{I}_{\mathrm{pa}}$ $(\mu \mathrm{A})=-4.09+0.63 \mathrm{v} ; \mathrm{r}=0.9989$ and $\mathrm{I}_{\mathrm{pc}}(\mu \mathrm{A})=-1.49-$ $0.62 \mathrm{v} ; \mathrm{r}=0.9931$, for peaks I and II, respectively as shown
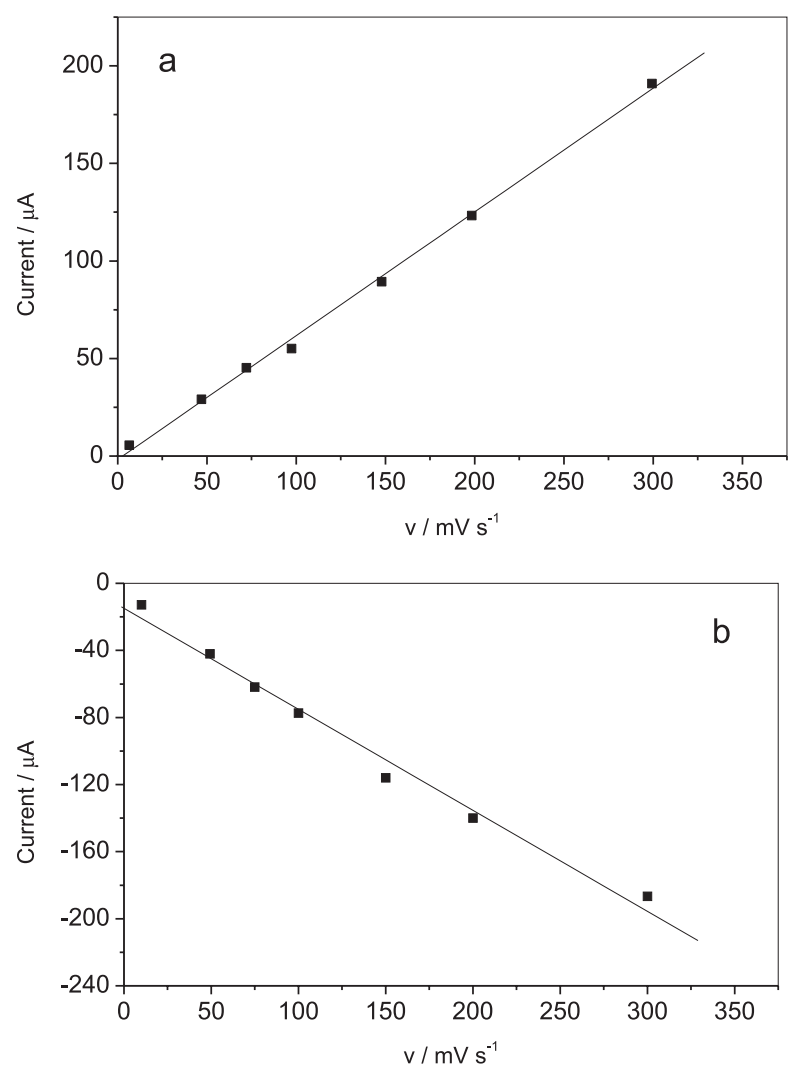

Figure 4. Dependence of the oxidation (a: peak I) and reduction (b: peak II) quasi-reversible peak current on the scan rate evaluated to $3.0 \mathrm{mmol} \mathrm{L}^{-1} \mathrm{MP}$. 
in Figure 4. This indicates that the electrode process was controlled by adsorption rather than diffusion. In addition, there was a linear relation between $\log \mathrm{I}_{\mathrm{p}}$ and $\log \mathrm{v}$, corresponding to the following equation: $\log \mathrm{I}_{\mathrm{pa}}=-6.31+$ $1.04 \log v ; r=0.9997$ and $\log I_{p c}=-6.39+1.12 \log v$; $\mathrm{r}=0.9962$, for peaks I and II, respectively (Figure 5). The slopes of 1.04 and 1.12 are close to the theoretically expected value of 1.00 for an adsorption controlled process.$^{29}$ The peak potential shifted to more positive values with increasing the scan rates as a consequence of the scan rate study.
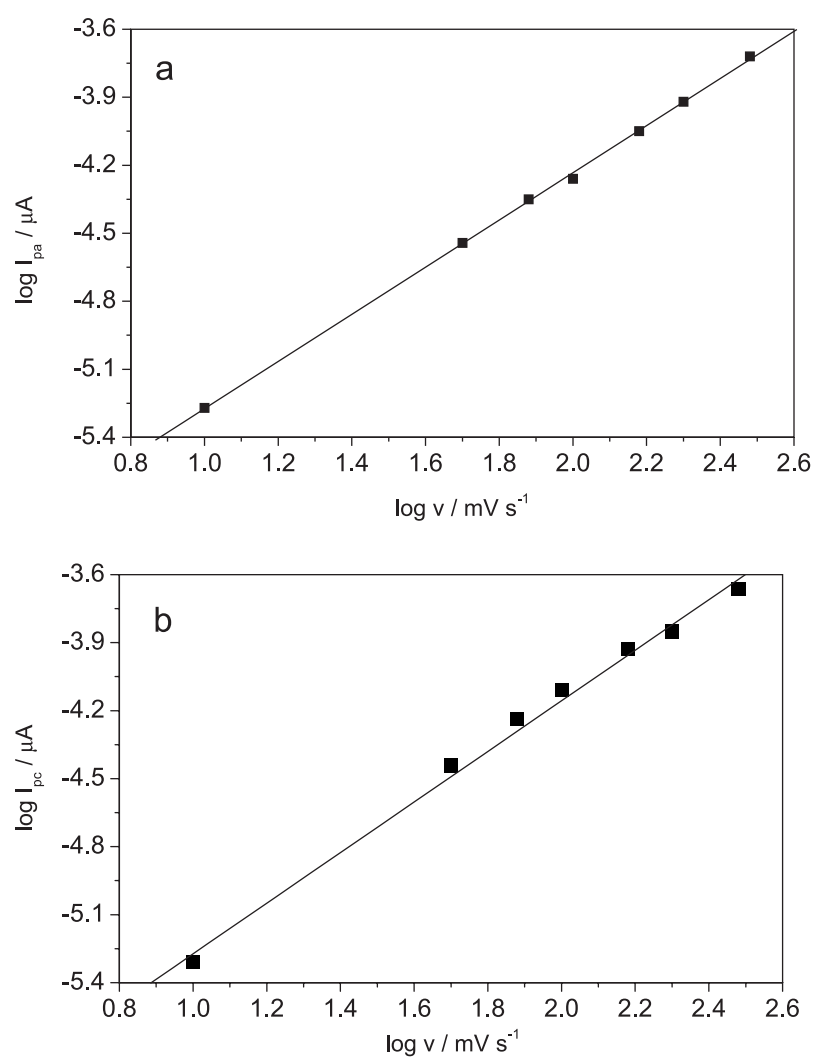

Figure 5. Dependence of the logarithm of peak current on logarithm of scan rate for oxidation (a: peak I) and reduction (b: peak II) of $3.0 \mathrm{mmol} \mathrm{L}^{-1} \mathrm{MP}$.

Influence of amount of graphite dispersed in deionized water

In order to develop a voltammetric method for determining the MP, the SWV mode was selected, because the peak is sharper and better defined at lower concentrations of MP than those obtained by linear sweep and differential-pulse voltammetric techniques. As a consequence a lower background current was used resulting in improved resolution for the MP reversible peak obtained previously by $\mathrm{CV}$ measurements. Figure 6 shows that the amount of graphite influences the peak current monitored at $+0.072 \mathrm{~V}$ using SWV. When the amount of graphite droplets is between 5.0 to $20 \mu \mathrm{L}$, the peak current is more stable and higher. Beyond $20 \mu \mathrm{L}$, it decreases. This is related to the thickness of the film. If the film is too thin, the MP amount adsorbed is small, resulting in a small peak current. If it is too thick, the film conductivity is reduced and the film becomes less stable as graphite leaves the electrode surface. Thus, graphite can block the electrode surface and hence cause a decrease in the peak current. With $20 \mu \mathrm{L}$ of graphite, the peak current was highest but not reproducible as with $10 \mu \mathrm{L}$. Therefore, the $10 \mu \mathrm{L}$ graphite suspension solution was used in the remaining experiments.

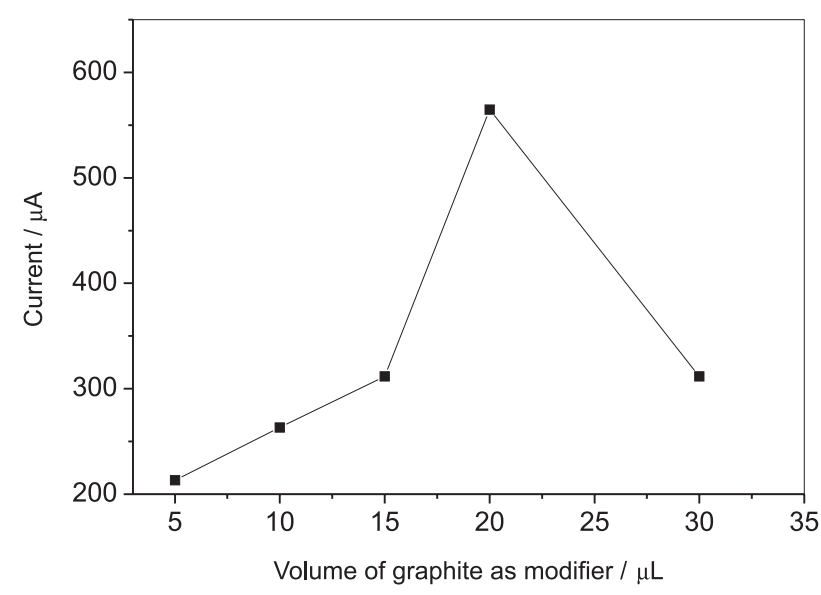

Figure 6. Influence effect of the amount of graphite dispersed in deionized water with the optimized SWV parameters on the $3.0 \mathrm{mmol} \mathrm{L}^{-1} \mathrm{MP}$ in supporting electrolyte $0.20 \mathrm{~mol} \mathrm{~L}^{-1}$ acetate buffer $\mathrm{pH}$ 5.2. SWV conditions: scanning potential range -0.30 to $+0.30 \mathrm{~V}$; frequency $50 \mathrm{~Hz}$; potential increment (step potential) $1 \mathrm{mV}$; amplitude of the square-wave $100 \mathrm{mV}$.

\section{Influence of accumulation potential and time}

It is important to fix the accumulation potential $\left(\mathrm{E}_{\text {deposit }}\right)$ and time when adsorption studies were undertaken for analytical purposes, using electrochemical anodic stripping. Both conditions could affect the amount of adsorption of MP at the graphite-modified bppg electrode because the nitro group of MP is reduced at maximum rate giving the corresponding hydroxylamine product which in turn is responsible of peaks I and II at about $0 \mathrm{~V}$. Bearing this in mind, the effect of accumulation potential and time on peak current response was studied by SWV as shown in the Figure 7. The concentration of MP used was $5.0 \mathrm{mmol} \mathrm{L}^{-1}$.

When accumulation potential varied from -1.0 to $+0.0 \mathrm{~V}$, the peak current changed significantly. The peak current decreased very rapidly with increasing potential until + 0.0 V. Rapid adsorption of MP was observed on the surface of the modified electrode at $-1.0 \mathrm{~V}$. The rapid and highly effective accumulation of MP was attributed to the macroporosity, heterogeneity and hydrophobicity of graphite, which exhibited strong affinity to the organophosphorous 


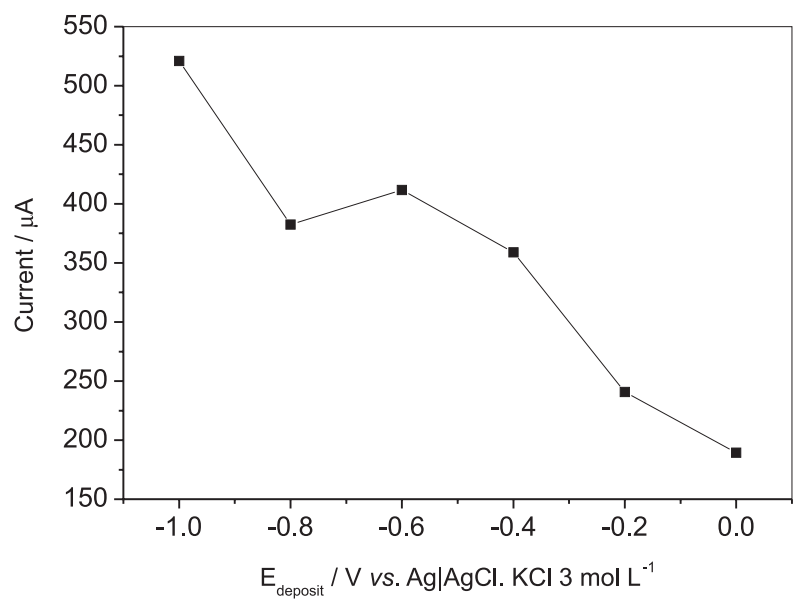

Figure 7. Relationship between accumulation potential $\left(\mathrm{E}_{\text {deposit }}\right)$ for the $3.0 \mathrm{mmol} \mathrm{L}^{-1} \mathrm{MP}$ oxidation peak current in supporting electrolyte $0.20 \mathrm{~mol} \mathrm{~L}^{-1}$ acetate buffer pH 5.2. SWV conditions: as described in Figure 6.

compound MP. The peak current reached the maximum after $60 \mathrm{~s}$ and then remained unchanged. This indicates the saturation accumulation level on the surface of the electrode. As a long period of accumulation might reduce the stability of the graphite film, $60 \mathrm{~s}$ was chosen as standard accumulation time. Additionally, all of these results were used in the following SWV optimization parameters.

\section{Optimization of $S W V$ conditions}

After the evaluation of the optimal conditions for the modification of the bppg-electrode with graphite, the optimal parameters for the SWV technique that yielded the best results for MP stripping analysis were assessed. Initially, three parameters were tested: amplitude, step potential and frequency (all of the measurements were carried out using univariate tests). The amplitude varied in the range of $10-100 \mathrm{mV}$, fixing the frequency at $50 \mathrm{~Hz}$ and step potential at $4.5 \mathrm{mV}$. The best result was defined with the parameters that cause no deformation of the peak potential or any significant increase in peak width. As a consequence, $100 \mathrm{mV}$ was chosen as the square-wave amplitude. Secondly, the frequency was evaluated in the range of 10-100 Hz, maintaining amplitude of $100 \mathrm{mV}$ and a step potential of $4.5 \mathrm{mV}$. It should be noted that, according to GPES 4.9 software version, the potential step (or potential increment) together with the frequency defines the effective scan rate of SWV mode. The best voltammograms were obtained using $50 \mathrm{~Hz}$ for the analysis of MP. The response of peak currents increases up to $80 \mathrm{~Hz}$ and after that point remains stable (with a slight reduction of peak current and no deformation in the voltammetric shape of MP oxidation process). Finally, by fixing the amplitude at $100 \mathrm{mV}$ and the frequency at $50 \mathrm{~Hz}$, the effect of potential step increment was studied in the range of 1-10 $\mathrm{mV}$. For potential steps greater than $1 \mathrm{mV}$, the current peak was observed to decrease in height for MP. Therefore, for the optimized conditions, the analysis of MP in graphitemodified bppg electrode was carried out using amplitude of $100 \mathrm{mV}$, frequency of $50 \mathrm{~Hz}$ and step potential of $1 \mathrm{mV}$ (corresponding to an effective scan rate of $50.0 \mathrm{mV} \mathrm{s}^{-1}$ ).

\section{Calibration curve}

According to the observed SWV results, it was possible to apply this technique to the quantitative analysis of MP. The $0.2 \mathrm{~mol} \mathrm{~L}^{-1}$ acetate buffer solution ( $\mathrm{pH}$ 5.2) was selected as the supporting electrolyte for the quantification of MP giving the maximum peak current. The peak at about $+0.074 \mathrm{~V}$ was considered most appropriate for the analysis. Anodic stripping square-wave voltammograms obtained with increasing amounts of MP demonstrate that the peak current increased linearly with increasing concentration (Figure 8). Using the optimum conditions described above, linear calibration curves were obtained for MP in the range of 79.0 to $263.3 \mu \mathrm{mol} \mathrm{L}{ }^{-1}$. The linear equation was $I_{p}(\mu \mathrm{A})=-87.82+1.00[\mathrm{MP}](\mathrm{r}=0.9993$, [MP] is in $\left.\mu \mathrm{mol} \mathrm{L} \mathrm{L}^{-1}\right)$. Deviation from linearity was observed for more concentrated solutions (up than $350.0 \mu \mathrm{mol} \mathrm{L}^{-1}$ ), due to the adsorption of MP or its redox product on the electrode surface. The limit of detection (LOD) and quantification (LOQ) were 3.00 and $10.0 \mu \mathrm{mol} \mathrm{L}^{-1}$, respectively. The LOD and LOQ were calculated using the following equations:

$\mathrm{LOD}=3 \mathrm{~s} / \mathrm{m} ; \quad \mathrm{LOQ}=10 \mathrm{~s} / \mathrm{m}$

where $s$ is the standard deviation of the peak currents of the blank (twelve runs), and $\mathrm{m}$ is the slope of the calibration

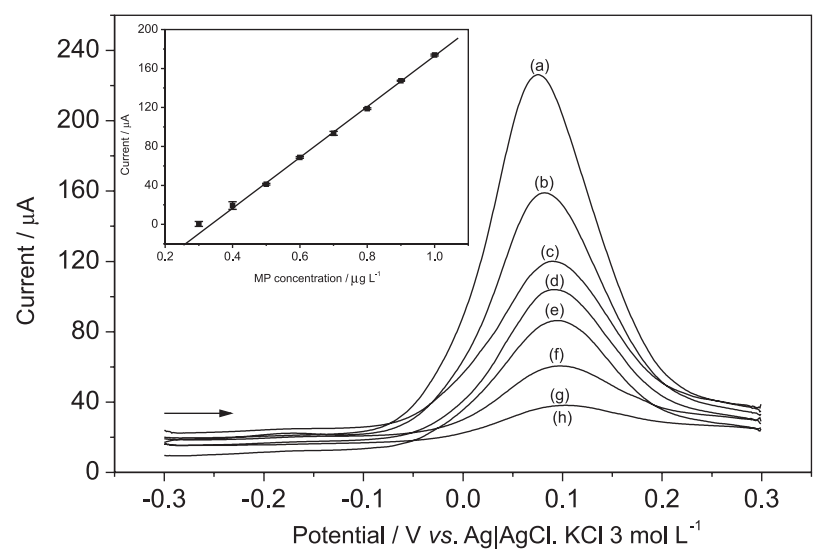

Figure 8. SWV optimized responses for different MP concentrations: (a) 263.3 (b) 237.0 (c) 210.7 (d) 184.3 (e) 158.0 (f) 131.7 (g) 105.3 (h) $79.0 \mu \mathrm{mol} \mathrm{L}^{-1}$ in supporting electrolyte $0.20 \mathrm{~mol} \mathrm{~L}^{-1}$ acetate buffer pH 5.2 and volume of graphite suspension as a modifier of $10 \mu \mathrm{L}$. Inset: calibration curve for MP. 
Table 1. Recovery study of MP in the drinking water samples $(n=5)$

\begin{tabular}{lccc}
\hline Sample & Added $/ \mu \mathrm{g} \mathrm{L}^{-1}$ & Found / $\mu \mathrm{g} \mathrm{L} \mathrm{L}^{-1}$ & Recovery / $(\%)$ \\
\hline 1 & 55.0 & 54.2 & 98.5 \\
2 & 55.0 & 56.6 & 103 \\
3 & 55.0 & 56.2 & 102 \\
4 & 55.0 & 55.4 & 101 \\
5 & 55.0 & 5.95 & 101 \\
\hline
\end{tabular}

curve. The LOD obtained is satisfactory and less sensitive than those reported in literature, however these results clearly indicate that the proposed electrochemical method of analysis for the determination of MP pesticide is reliable, rapid and especially low-cost.

Additionally, to study the reproducibility of the electrode preparation procedure, a $263.3 \mu \mathrm{mol} \mathrm{L} \mathrm{L}^{-1} \mathrm{MP}$ solution was measured with the same electrode (with a renewed electrode surface with graphite as a modifier for each measurement) for several hours per day, the R.S.D. of the peak current was $10.8 \%$ (number of measurements $=12$ ). Between days reproducibility was similar to that of within day results without considerable variation.

\section{Analysis of drinking water}

In order to evaluate the applicability of the proposed method in the drinking water sample analysis, five samples were studied. Initially, voltammograms in sample solutions containing the supporting electrolyte and various aliquots of the drinking water were recorded and no oxidation peaks were observed in any of the five samples, demonstrating the absence of detectable residues of MP pesticide in these matrices. The procedures for the MP analysis followed a standard addition method carried out after the addition of known amounts of the MP to various samples ( 3 consecutive additions of $55.0 \mu \mathrm{mol} \mathrm{L}^{-1}$ ) with proposed contaminated samples with $55.0 \mu \mathrm{mol} \mathrm{L}^{-1}$. The results were consistent and demonstrated a clear linear relationship. The electrochemical response was satisfactory, and a recovery test of MP ranged from 55.0 to $220.0 \mu \mathrm{mol} \mathrm{L}^{-1}$ was also performed using anodic stripping SWV. The recoveries in different samples were in the range from 98.5 to $103 \%$, with each respectively R.S.D. estimated (Table 1).

Under the optimum experimental conditions, the effects of potential interferents on the voltammetric response of $55.0 \mu \mathrm{mol} \mathrm{L}^{-1} \mathrm{MP}$ were also evaluated. The experimental results (Table 2) show that a $1.00 \mathrm{mmol} \mathrm{L}^{-1}$ concentration of oxalic acid, citric acid, boric acid, sodium lauryl sulfate and sodium tartarate did not interfere with the voltammetric signal of MP pesticide for quantitative analysis purpose.
However, a concentration of sorbic acid had a significant influence on the voltammetric signal of MP.

Table 2. Influence of potential interferents on the voltammetric response of $79.0 \mu \mathrm{mol} \mathrm{L}^{-1} \mathrm{MP}(\mathrm{n}=5)$

\begin{tabular}{lcc}
\hline Interferent & $\begin{array}{c}\text { Concentration / } \\
\text { mmol L }^{-1}\end{array}$ & $\begin{array}{c}\text { Signal change / } \\
(\%)\end{array}$ \\
\hline Oxalic acid & 1.0 & +5.20 \\
Citric acid & 1.0 & +2.20 \\
Boric acid & 1.0 & -8.91 \\
Sorbic acid & 1.0 & +151.8 \\
Sodium lauryl sulfate & 1.0 & -2.92 \\
Sodium tartarate & 1.0 & -9.94 \\
\hline
\end{tabular}

\section{Conclusions}

In this work, a graphite-modified bppg electrode has been successfully developed for oxidation of MP in a $0.20 \mathrm{~mol} \mathrm{~L}^{-1}$ acetate buffer solution (pH 5.2). Graphite powder showed greater sensitivity action for the oxidation of MP, characterized by the enhancement of the peak current, which was probably due to the larger surface area of graphite attached to the electrode. The peak at about $+0.074 \mathrm{~V}$ was suitable for analysis and the peak current had a linear relationship with MP concentrations over a certain range under the selected conditions. This sensor can be used for voltammetric determination of the analyte as low as $10.0 \mu \mathrm{mol} \mathrm{L} \mathrm{L}^{-1}$ with good reproducibility. The modified electrode was also been used to determine MP in drinking water samples. The proposed method offers the advantages of accuracy and time saving as well as simplicity of reagents, costs and apparatus. In addition, the results obtained in the analysis of MP in spiked drinking water samples demonstrate the high potential applicability of the method for real sample analysis.

\section{Acknowledgments}

We thank the Universidade Federal de Viçosa (UFV) and the Department of Chemistry for their support. The authors are also gratefully acknowledging the financial 
support of FUNARBE (FUNARPEQ), CNPq and also FAPEMIG without whom the work would not have been possible. Finally, we would like to thank Dr. Richard Ladle for English improvements.

\section{References}

1. Castanho, G. M.; Vaz, C. M. P.; Machado, S. A. S.; J. Braz. Chem. Soc. 2003, 14, 594.

2. Wang, J.; Anal. Chim. Acta 2004, 507, 3.

3. Wang, J.; Pumera, M.; Chatrathi, M. P.; Escarpa, A.; MusamehGreg, M.; Mulchandani, A.; Lin, Y.; Olsen, K.; Anal. Chem. 2002, 74, 1187.

4. Mulchandani, A.; Chen, W.; Mulchandani, P.; Wang, J.; Rogers, K. R.; Biosens. Bioelectron. 2001, 16, 225.

5. Fytianos, K.; Drimaropoulou, G.; Raikos, N.; Theodoridis, G.; Tsoukali, H.; J. AOAC Int. 2007, 90, 1677.

6. Tsoukali, H.; Theodoridis, G.; Raikos, N.; Grigoratou, I.; J. Chromatogr. B 2005, 822, 194.

7. Tsoukali, H.; Raikos, N.; Theodoridis, G.; Psaroulis, D.; Forensic Sci. Int. 2004, 143, 127.

8. Liapis, K. S.; Aplada-Sarlis, P.; Kyriakidis, N. V.; J. Chromatogr. A 2003, 996, 181.

9. Moate, T. F.; Furia, M.; Curl, C.; Muniz, J. F.; Yu, J.; Fenske, R. A.; J. AOAC Int. 2002, 85, 36.

10. Carabias, R. M.; Rodriguez, E. G.; Moran, M. J. A.; Hernandez, J. M.; J. Chromatogr. 1992, 607, 37.

11. Jaglan, P. S.; March, R. B.; Fukuto, T. R.; Gunther, F. A.; J. Agric. Food Chem. 1970, 18, 809.

12. Miles, J. W.; Dale, W. E.; J. Agric. Food Chem. 1978, 26, 480.

13. Huanga, G.; Ouyang, J.; Baeyensb, W. R. G.; Yanga, Y.; Taoc, C.; Anal. Chim. Acta 2002, 474, 21.

14. Mandal, A. K.; Adhikari, M.; J. Indian Chem. Soc. 1997, 74, 114.
15. Manzanilla-Cano, J. A.; Reyes-Salas, E. O.; Barceló-Quintal, M. H.; Int. J. Environ. Anal. Chem. 1999, 75, 387.

16. Zen, J. M.; Jou, J. J.; Kumar, A. S.; Anal. Chim. Acta 1999, 396, 39.

17. Agüí, L.; Yáñez-Sedeño, P.; Pingarrón, J. M.; Anal. Chim. Acta 2008, 622, 11.

18. Banks, C. E.; Compton, R. G.; Analyst 2006, 131, 670.

19. Banks, C. E.; Moore, R. R.; Davies, T. J.; Compton, R. G.; Chem. Commun. 2004, 16, 1804.

20. Banks, C. E.; Crossley, A.; Salter, C.; Wilkins, S. J.; Compton, R. G.; Angew. Chem., Int. Ed. 2006, 45, 2533.

21. Sljukic, B.; Banks, C. E.; Compton, R. G.; Nano Lett. 2006, 6, 1556.

22. Du, D.; Wang, M.; Zhang, J.; Cai, J.; Tu, H.; Zhang, A.; Electrochem. Comm. 2008, 10, 85.

23. Du, D.; Ye, X.; Zhang, J.; Zeng, Y.; Tu, H.; Zhang, A.; Liu, D.; Electrochem. Comm. 2008, 10, 686.

24. Du, D.; Ye, X.; Zhang, J.; Liu, D.; Electrochim. Acta 2008, 53, 4478.

25. Tan, X.; Li, B.; Zhan, G.; Li, C.; Electroanalysis 2009, 22, 151.

26. Xia, S.; Zhang, J.; Li, C.; Anal. Bioanal. Chem. 2010, 396, 697.

27. Wang, Z.; Chemia Analityczna 2009, 54, 403.

28. Wang, J.; Chatrathi, M. P.; Mulchandani, A.; Chen, W.; Anal. Chem. 2001, 73, 1804.

29. Moore, R. R.; Banks, C. E.; Compton, R. G.; Anal. Chem. 2004, 76, 2677.

30. Bard, A. J.; Faulkner, L. R.; Electrochemical Methods Fundamentals and Application, $2^{\text {nd }}$ ed., Wiley: New York, 2004.

Submitted: June 25, 2010

Published online: November 30, 2010

FAPESP has sponsored the publication of this article. 